\title{
ANALISIS FORM PUISI-PUISI NIZAR QABBBANI DALAM ANTOLOGI PUISI 100 RISALAH HUB
}

\author{
Halimi Zuhdy', M. Anwar Masadi ${ }^{2}$
}

\author{
1halimizuhdy81@gmail.com \\ 2Fakultas Humaniora UIN Maulana Malik \\ Fakultas Humaniora UIN Maulana Malik Ibrahim Ibrahim Malang \\ Malang \\ Bukit Cemara Tidar K2/3 Sukun Malang
}

\begin{abstract}
This research analyzes qualitative descriptively about form (language style) that is used by Nizar Qabbani. It is used by the researcher for expressing the meanings of Nizar Qabbani's poems. The results of this research shows that the researcher has found many of language styles usage used by Nizar Qabbani in his poems, like metaphor, simile, paralelisme, metominia, retoris, hyperbola, personification, etc. From the analyzing the poems, the researcher has found the meanings of them namely Ighdab poem that has angry, loving, and promise meaning. Aina Adzhabu poem means true love and lost feel. Then, Ukhibbuki Jiddann poem means true love. All of them are awesome love theme that expressed by Nizar Qabbani. He gives the meaning of love, faithful, and angry in frame of figurative language that is extremely exciting.
\end{abstract}

Keywords: Poems, New Criticism, Nizar Qabbani, Risalah Hubb

\section{PENDAHULUAN}

Imajinasi manusia selalu mengalami perkembangan dari masa ke masa, unik, dan bahkan sulit untuk diprediksi. Di antara imajinasi yang yang selalu tumbuh berkembang di dalamnya adalah karya sastra, ia karya imajinatif yang mempunyai fungsi estetik dan karakteristik masing-masing, baik itu puisi, prosa maupun drama. Salah satu hal dari ketiga genre tersebut, puisi merupakan bahan kajian yang menarik untuk diteliti mengingat memberikan banyak bahasa kias didalamnya. Puisi menggunakan bahasa bahasa yang lebih padat dan simbolik dari dua genre sastra yang lain. Pradopo (2002, h. 6) menjelaskan bahwa puisi merupakan hasil aktivitas pemadatan, yaitu proses penciptaan dengan cara menangkap kesan-kesan lalu memadatkannya (kondensasi). Puisi memiliki unsur-unsur berupa emosi, imajinasi, pemikiran, ide, nada, irama, kesan panca indera, susunan kata, kata-kata kiasan, kepadatan, dan perasaan pengarang. Hal inilah yang menjadikan bahasa puisi lebih sulit dan mempunyai kerumitan dalam menangkap maknanya.

Tingkat kesulitan dalam memahami puisi, dibutuhkan pendekatan guna memahami bentuk dan makna puisi secara utuh. Pendekatan yang tepat untuk membedah makna puisi secara otonom adalah pendekatan new criticism. Menurut (Hawkes dalam Siswantoro, 2010.h. 22) karya sastra harus dipahami sebagai karya yang otonom, tanpa melibatkan rujukan maupun kriteriakriteria diluar dirinya.

Fokus penelitian ini yang pertama adalah pada gaya bahasa, hal tersebut peneliti pilih karena gaya bahasa adalah sarana untuk menguraikan makna sebuah puisi. Tanpa menguraikan gaya bahasa, maka puisi hanya akan dipenuhi simbol-simbol yang sangat sulit untuk dicerna. Analisis ini menitikberatkan pada puisi-puisi Nizar Qabbani Ighdhab, Achabbuki Jiddan dan Aina Adzhabu.

Objek material dari penelitian ini adalah puisi-puisi Nizar Qabbani dalam antologinya yang berjudul 100 Risalah Hub. Dari hasil kajian penulis, beberapa puisi Nizar 
Qobbani diteliti dengan berbagai pendekatan dan kajian diantaranya; At-Tanash (Musthafa, 2012) Muqoribah al-Nash (Zuhdy, 2015), Rukyah wa Tasykil (Qowamisy, 2013), Uslubiyah (Shaleh, 2012) Puisi-puisi Nizar Qabbani tersebut menarik untuk dikaji dengan pendekatan new criticism karena penuh dengan bentuk gaya bahasa paradok, ironi dan lain-lain. Alasan dianalisisnya puisi-puisi Nizar Qabbani, karena tingkat kepenyairan Nizar Qabbani. Puisi-puisinya yang bergenre bebas (puisi bebas) menandakan kebebasan Nizar Qabbani dalam berekspresi dalam puisipuisinya. Kebebasannya terlihat dalam puisipuisinya yang tidak hanya bertemakan politik seperti dunia yang digelutinya. Bahkan bisa dikatakan kebanyakan puisi-puisi Nizar Qabbani adalah bertemakan cinta. Puisi-puisi yang bertemakan cinta tersebut menjadikan Nizar Qabbani dijuluki oleh dunia arab sebagai 'Penyair Cinta' karena sarat makna, nilai, dan metafora sehingga menggugah perasaan orang-orang Arab.

Atas dasar pertimbangan di atas, penelitian ini menggunakan pendekatan New Criticism yang bersifat otonom. New Criticism tidak membutuhkan perangkat seperti sosiologi, filsafat, sejarah dan lain-lain untuk mengungkapkan maksud yang terkandung dalam puisi-puisi tersebut.

The introduction should clearly state the purpose of the paper. It should include key references to appropriate work but should not be an historical or literature review. The contents of the paper include Introduction, Method (for research-based articles), Content, Conclusion, and References. The content of non-research based articles may include some sub-chapters with a free title depends on the study.

\section{New Criticism}

New Criticism merupakan aliran baru dalam sastra. Aliran ini diperkenalkan dan baru berkembang tahun 1930 (Suroso dkk, 2008,h. 30). Istilah new criticism pertama kali dikemukakan oleh John Crowe Ransom dalam bukunya The New Criticism (1940) dan ditopang oleh I.A. Richard dan T.S. Eliot. Sejak Cleanth Brooks dan Robert Penn Warren menerbitkan buku Understanding Poetry (1938), model kritik sastra ini mendapat perhatian yang luas di kalangan akademisi dan pelajar Amerika selama dua dekade.
Penulis new criticism lainnya yang penting adalah: Allen Tate, R.P. Blackmur, dan William K. Wimsatt, Jr. (Abrams, 1981,h. 109 -110).

New Criticsm memandang bahwa teks sastra sebagai suatu sistem dan suatu struktur yang utuh. Sebagai suatu sistem/struktrur karya sastra dibangun oleh komponenkomponen teks sastra yang saling berkaitan satu sama lain membentuk suatu bentuk makna. Unsur-unsur yang membangun teks sastra dan kaitannya dalam membentuk sistem.

Pandangan New Criticism, tentang sastra merupakan figur yang spesial, satu objek swadaya (self-sufficient) yang sama solidnya dan bersifat material. Sastra adalah sesuatu yang otonom, mandiri dan tidak tergantung pada unsur-unsur lain di luar sastra. Oleh karena itu, sastra menjadi objek dalam dirinya sendiri, harus terpisah dari pengarang maupun pembaca. Pendekatan semacam itu membuat New Criticism dikenal sebagai pendekatan yang memiliki sifat ergosentrik; . pendekatan yang mengarahkan perhatian kepada karya sastra sendiri (ergosentris), lepas dari pengarung pengarangnya (intentional fallacy), riwayat terjadinya serta pendapat pembaca (affective fallacy) dan kaum kritisi (herey of paraphrase).

Sastra bagi new criticism adalah sesuatu yang unik dan mempunyai bentuk yang sangat baik, sehingga selayaknya harus didekati dari dirinya sendiri, tak ada yang ditambah ataupun dikurangi. Penganalisisan New Criticism hanya meaning, yaitu makna karya itu, dan hanya itulah yang dapat dipahami dan dikupasnya, tanpa mengikutsertakan niat atau maksud pengarang (intentional fallacy).

Para new criticism menganggap berbagai model kritik yang berorientasi kepada aspek-aspek di luar (ekstrinsik) karya sastra sebagai suatu kesalahan besar. Orientasi kepada maksud pengarang disebut sebagai suatu penalaran yang sesat. Makna sebuah puisi tidak boleh dikacaukan dengan kesan yang diperoleh pembaca karena dapat terjerumus dalam struktur sintaksis dan semantik. Untuk mengetahui arti itu kita harus mempergunakan pengetahuan kita mengenai bahasa dan sastra.

New Criticsm berpendapat bahwa karya sastra (termasuk puisi) merupakan kesatuan yang telah selesai, sebuah gejala 
estetik yang bersifat objektif. Sastra sangat terhindar dari sifat subyektif. Menurut Wimsatt (dalam Hartoko, 1989,h. 52) sajak jangan dicampurkan dengan kesan (affect) yang diperoleh oleh pembaca. Jika mengikuti affect fallacy itu, maka akan terjerumus dalam kritik subyektivis dan impresionis. Menurut Brooks (dalam Hartoko, 1989,h. 53) kesatuan yang merupakan ciri khas sebuah sajak tidak dapat diparafrasekan, diuraikan dengan cara "biasa". Sebuah sajak dapat diumpamakan dengan sebuah drama. Dalam sebuah sajak pun dipentaskan sesuatu, terdapat ketegangan-ketegangan antara unsurunsurnya dan ketegangan tersebut dipecahkan lewat konflik.

Jean Peaget dikutip dari Hewkes $(1977$, h. 141) memberi tiga macam ciri stuktur, pertama gagasan menyeluruh. Kedua, gagasan intrinsik. Ketiga, gagasan transformasi yang memungkinkan pembentukan penafsiran baru. Keempat, gagasan diri yang berarti bahwa stuktur itu bersifat otonom.

Roland Barthes dikutip dari Damono (1979,h. 40) menjelaskan ciri khas pendekatan ini. Pertama, perhatian tertuju kepada keseluruhan kepada totalitas. Kedua, tidak hanya menelaah stuktur (permukaan) lahir, tetapi juga struktur batin. Ketiga, struktur tidak ersifat anti kausal, yaitu tidak menyangkut karya sastra dengan sesuatu yang lain.

Maren Grisbach dikutip dari Junus (1985,h. 17) memberikan tiga ciri kakateristik sebuah struktur. Pertama, dalam struktur ada hubungan antara unsur-unsur sebuah karya sastra yang merupakan suatu system interaksi antar unsur-unsurnya pembentuknya. Kedua, dalam struktur ada suatu yang abstrak yang menyatukan hal-hal yang berbeda untuk memperoleh hokum universal. Ketiga, struktur tidak menyangkut tinjauan historis.

Menurut Teeuw (1984,h. 123) prinsip struktur yakni: kesatuan, keseluruhan, kebulatan, dan keterjalinan (Wholeness, unity, complexity, coherence). Pengertian tersebut menunjukkan bahwa unsur-unsur dalam suatu struktur tersebut membentuk suatu totalitas dan bahwa antara unsure unsur dalam suatu struktur tersebut terdapat saling jalinmenjalin makna. Makna salah satu unsur ditentukan oleh unsur lainnya dan juga ditentukan oleh makna totalitasnya. Unsur- unsur tersebut membentuk kesatuan yang utuh dan bulat artinya kesatuan yang unsurunsurnya masih nampak.

Prinsip yang mendasari teknik analisis New Critcism adalah (1) struktur bertujuan membongkar dan memaparkan secermat, seteliti, semendetail dan sedalam mungkin keterkaitan dan keterjalinan unsurunsur karya sastra yang membentuk makna menyeluruh, (2) struktur tidak menjumlahkan unsur-unsur, (3) struktur berusaha menyemantikkan hubungan struktur yang ada dalam puisi. Hubungan struktur ini biasa ditandai dengan hunbungan kohesif baik pada tingkat struktur morfologis, struktur sintaksis maupun struktur semantik dan (4) struktur menganggap bahwa keseluruhan makna karya sastra berada pada keterpaduan struktur total.

\section{Langkah Kerja New Criticism}

Yusuf (2009,h. 16) merumuskan metode penelitian new criticism. Pertama, close reading atau pembacaan tertutup tanpa melibatkan diluar karya tersebut, yakni dengan mencermati karya sastra dengan teliti dan mendetail baris demi baris, kata demi kata, dan sampai ke akar-akar katanya. Kedua, empiris, yakni penekanan analisis. Ketiga, Otonomi. Keempat, Concreteness. Apabila karya sastra dibaca, maka karya satra menjadi concrete atau hidup. Kelima, bentuk (form): titik berat kajian new criticism adalah bentuk (form) karya sastra, yaitu keberhasilan penyair atau penulis dalam diksi (pemilihan kata), imagenary (metaphor, simile, onomatopea), paradoks, ironi, dan sebagainya.

\section{ANALISIS PUISI NIZAR QABBANI}

Titik berat kajian new criticism adalah bentuk (form) karya sastra, yaitu keberhasilan penyair atau penulis dalam diksi (pemilihan kata), imagenary (metaphor, simile, onomatopea, dan sebagainya), paradoks, ironi, dan sebagainya. Bentuk karya sastra menentukan isi karya sastra.

Dalam analisis gaya bahasa terhadap puisi Ighdab terdapat berbagai macam gaya bahasa yang berhasil diungkap antara lain Simile yaitu sebagai gaya bahasa yang membandingkan dua objek dengan kata kiasan tertentu. Kata Ka-at Thifl berarti seperti anak kecil. Penggambaran objek yang dilakukan oleh penulis mengindikasikan 
bahwa penulis ingin memberikan kekuatan makna dengan menghadirkan kata seperti anak. Kata Ka-at Thifl juga terdapat dalam baris setelahnya /Wa 'Indamā Tahtaju Ka-at Thifl ilā Chanāny/ jika engkau membutuhkan, maka engkau seperti anak kecil yang butuh belas kasihan. Kata Ka-at Thifl yang kedua berfungsi juga sebagai penegasan ungkapan yang pertama.

Gaya bahasa metafora juga muncul pada puisi Ighdab. Metafora adalah gaya bahasa perbandingan ang membandingkan dua obyek tertentu tanpa menggunakan kata pembanding seperti. Pada bait ini tampak perbandingan Jika tidak ada gelombang, maka tidak akan ada samudra dari kata tersebut nampak penyair membandingkan hukum sebab akibat dengan gelombang dan badai, atau lebih mudahnya dijelaskan jika tidak ada sesuatu, maka tidak mungkin ada rasa marah yang besar seperti marahnya gelombang, hal itu dikarenakan ada hubungan sebab akibat antara badai dan gelombang. Gelombang yang dahsyat dan besar akan datang jika ada badai yang kuat juga. Penggambaran metafora juga tampak dalam bait berikut Engkau adalah bumi dan langit. Bagi penyair, engkau adalah seperti halnya bumi yang sangat indah, dan begitu mulia seperti langit. Pengambaran objek yang dilakukan oleh penulis menandakan begitu besar dan kuatnya cinta penulis terhadap sang kekasih.

Majas Paralelisme juga tampak dalam puisi tersebut. gaya bahasa pengulangan seperti repetisi yang khusus terdapat dalam puisi. Pengulangan di bagian awal dinamakan anafora, sedang di bagian akhir disebut epifora. Kata Jadilah badai...jadilah hujan adalah bentuk Paralelisme Anafora. Paralelisme anafora terjadi karena adanya pengulangan diawal kalimat. Paralelisme Epifora juga tampak dalam kutipan berikut Marahlah seperti kau mau/ Lukai rasaku seperti kau mau/, pengulangan epifora seakanakan memberikan penegasan dan penguatan makna terhadap kepasrahan penyair kepada kekasihnya.

Gaya bahasa lain yang terdapat dalam puisi tersebut adalah metominia. Metominia adalah bahasa kias pengganti nama, yaitu berupa penggunaan atribut sebuah obyek atau penggunan sesuatu yang sangat dekat dengan objek yang digantikan (Prapdopo, 200,h. 77). Kata "lukai rasaku" adalah merupakan metominia dari menyakiti perasaan. Kata "Jirakh" bermakna luka yang teramat dalam. Luka teramat dalam sangatlah sakit, sehingga penulis menggunakan metominia melukai yang dalam untuk menggantikan kata menyakiti perasaan.

Gaya Bahasa retoris adalah gaya bahasa penegasan yang menggunakan kalimat tanya, tetapi sebenarnya tidak bertanya. Gaya bahasa ini biasanya digunakan untuk penegasan suatu masalah. Gaya bahasa Retoris tampak dalam kutipan puisi berikut /engkau seperti anak kecil yang berbuat siasia/ Yang dipenuhi dengan tipuan /Bagaimana waktu kecilnya/. Kata "bagaimana waktu kecilnya" merupakan penegasan dan penguatan untuk kalimat sebelumnya. Perilaku marah yang dilakukan oleh kekasih si aku adalah marah seperti anak kecil yang dipenuhi dengan tipuan.

Dari penggambaran bentuk gaya bahasa di atas dapat diungkapkan bahwa makna dari puisi Ighdab adalah amarah, cinta, dan janji. Rasa amarah tampak dalam judul puisi Ighdab. Ighdab merupakan fi'il amar dari kata Ghadaba yang berarti marahlah. Pada bait pertama tampak bahwa si aku menyuruh marah terhadap kekasihnya, menyuruh untuk melukai perasaannya, menyuruh untuk meluapkan amarahnya dengan memecahkan pot-pot bunga dan memecahkan kaca bahkan menyuruh kekasihnya untuk mengancam akan mencintai orang lain selain dia. Penggambaran sifat marah juga tampak dalam bait selanjutnya si aku tampak menggambarkan rasa marah kekasihnya, namun satu sisi si aku juga menggambarkan bagaimana kecantikan kekasihnya. Rasa marah kekasih aku juga digambarkan seperti sebagai badai dan hujan. Marah yang seperti badai dan gelombang adalah marah yang luar biasa. Walaupun kekasih si aku marah seperti hujan dan badai, karena cinta si aku yang begitu besar, maka si aku selalu memaafkan kesalahan kekasihnya.

Si aku merasa marahnya sang kekasih seperti sikap seorang anak kecil yang sia-sia yang penuh dengan tipuan, sehingga rasa marah kekasih aku terhadapnya akan sia-sia. Cinta yang begitu besar si aku terhadap kekasihnya tidak bisa membuatnya marah, dan menganggap marah kekasihnya seperti marah anak kecil. Di sisi lain jika sang kekasih bosan si aku menyuruhnya pergi. Namun lagi- 
lagi karena cintanya yang begitu besar si aku sangat sedih dengan kepergiannya /Adapun aku, maka aku / Akan mencukupkan dengan air mata dan kesedihan / Diam adalah keangkuhan / Kesedihan adalah keangkuhan. Sebelum kepergian kekasihnya, si aku tak lupa berpesan untuk kepadanya kapan saja dia mau. Rasa cintanya yang begitu besar terhadap kekasihnya menyebabkan dia bisa memaafkan segalaa kesalahan kekasihnya, bahkan meminta kepada kekasihnya untuk kembali padanya kapan saja dia mau. Hal tersebut tampak dalam kutipan puisi berikut Pergilah pada hatiku kapan kau mau / Engkaulah dalam kehidupan anganku / Engkau...adalah bumi dan langit.

Dalam puisi Aina Adzhabu terdapat beberapa gaya bahasa. Gaya bahasa hiperbola ini dimanfaatkan oleh penyair untuk menggambarkan obyek, ide dan lain-lain dengan memberikan bobot tekanan secara berlebihan untuk memperoleh efek yang instan (Siswantoro, 2005,h. 34). Kata Setiap hari...aku merasa engkau begitu dekat / Setiap hari...aku merasa wajahmu sebagai hukuman. Dari bait tersebut pennyair tampak ingin mengatakan bahwa dia sangat kehilangan dengan kepergian kekasihnya (Dariya). Setiap hari, sejak kepergian Dariya, ia merasa seakan-akan Dariya masih begitu dekat dengannya, menemaninya setiap waktu. Namun ketika ia sadar bahwa Dariya telah pergi, ia merasa sedih sekali, ia seakan-akan merasa sebagai seorang yang terhukum karena kepergian Dariya. Perasaan terhukum digambarkan secara berlebihan oleh penulis dengan memberikan gaya bahasa Hiperbola Wajahmu menjadi hukuman.

Gaya hiperbola lain tampak dalam kutipan puisi berikut Sungguh diriku terhadap dirinya sangat kagum / Puisi-puisi tinggal ditaman-taman matanya / Jika bukan karena matanya...tidak akan ada puisi yang ditulis. Penulis tampak ingin menggambarkan kekaguman terhadap kekasihnya sehingga muncul cinta yang begitu besar terhadapnya. Penyair menggambarkan keindahan dan kecantikan kekasihnya dengan mengatakan Puisi-puisi tinggal ditaman matanya penggunaan kata puisi-puisi tinggal ditaman matanya merupakan upaya penulis untuk menggambarkan kecantikan dan keindahan kekasihnya. Bagi penulis, mata kekasihnya merupakan wakil dari kecantikan dan keindahan dirinya, penulis menambahkan dengan memberikan gaya bahasa hiperbola bahwa pusi-puisi tinggal di taman-taman matanya. Seperti kita ketahui, taman secara denotatif berarti kebun yang indah untuk rekreasi dan bersantai. Penggunaan kata taman mata untuk mengambarkan bahwa keindahan dan kecantikan kekasihnya adalah inspirasi penulis untuk membuat puisipuisinya. Hal itu ditegaskan dengan bait selanjutnya "jika bukan karena matanya...tidak akan ada puisi yang ditulis".

Gaya bahasa Simile juga tampak dalam puisi Aina Adzhabu. Hal tersebut tercermin dalam kutipan berikut /Telah meresap di poripori kulitku / Seperti setetes embun, meresap. Kata "seperti setetes embun", merupakan bentuk dari gaya bahasa simile. Kata seperti embun bermakna bahwa kelembutan Dariya adalah seperti embun yang menyejukkan hatinya, bahkan pada baris sebelumnya dikatakan, bahwa setetes embun yang merupakan bentuk dari kelembutan kekasihnya yang menyejukkan telah meresap didalam pori-pori kulitnya. Hal tersebut menandakan bahwa kekasihnya tersebut adalah orang yang sangat berarti bagi dirinya.

Gaya bahasa antithesis juga tampak dalam puisi tersebut. Gaya bahasa Antitesis adalah gaya bahasa penegasan yang menggunakan paduan kata-kata yang artinya bertentangan. Gaya bahasa antitesis tampak dalam kutipan puisi berikut /Kepergianmu, membuat suli untuk biasa / Kehadiranmu, membuatku lebih sulit/. Dalam kutipan puisi tersebut tampak kata-kata "Kepergianmu dan kehadiranmu", dalam kata-kata tersebut terdapat pertentangan antara kepergian dan kehadiran. Kata-kata tersebut digunakan oleh penulis untuk menegaskan bahwa keberadaan dan kepergian kekasihnya adalah suatu hal yang sulit. Kepergiannya merupakan kesedihan baginya, hal tersebut karena rasa cintanya yang begitu besar, sedangkan keberadaan kekasihnya adalah merupakan suatu hal yang juga sulit, hal tersebut karena konflik-konflik yan terjadi antara dirinya dan kekasihnya.

Dari pengungkapan form diatas, maka dapat dilihat makna dari puisi Aina Adzhabu adalah cinta sejati dan rasa kehilangan terhadap kepergian Dariya. Kepergian Dariya (kekasih aku) adalah akibat dari sikap dan pertengkaran antara Dariya dan si aku. Puisi 
ini diawali dengan ungkapan kepergian Dariya /Dariya belum kembali / Setiap hari...aku merasa engkau begitu dekat / Setiap hari...wajahmu menjadi hukuman. Dari kutipan puisi diatas, tampak bagaimana si aku sangat kehilangan Dariya, si aku merasa harus kemana lagi untuk mencarinya. Seakan-akan si aku sudah sangat lelah dalam mencari Dariya. Hal itu dikarenakan cintanya yang begitu besar kepada Dariya. Bahkan kepergian Dariya menyisakan kesedihan yang sangat dalam. Walaupun Dariya sudah pergi jauh, namun karena cinta si aku yang begitu dalam menyebabkan si aku merasa Dariya begitu dekat. Namun berbagai kesalahan yang dibuatnya seakan-akan si aku merasa terhukum akibat segala kesalahannya.

$$
\text { Pada bait selanjutnya tampak }
$$

bagaimana pengambaran cinta si aku terhadap Dariya yang begitu besar. Bagaimana aku...bagaimana aku mencintaimu, sehingga / Diriku terhadap dirinya sangat kagum / Puisi-puisi tinggal ditaman matamu / Jika bukan karena matamu, tidak aka nada puisi yang ditulis. Dari kutipan puisi ditasa tampak sekali bagaimana kekaguman dan rasa cinta yang begitu dalam si aku terhadap Dariya. Bahkan cintanya yang begitu dalam menyebabkan si aku bertanya-tanya kepada dirinya sendiri "bagaimana aku...bagaimana aku mencintaimu". Kemudian pada baris selanjutnya diungkapkan kekaguman si aku terhadap kekasihnya "jiwaku (aku) terhadap dirinya sangat kagum" penggunaan kata Nafsun yang berarti jiwa mempunyai arti dan penekanan bahwa cinta aku terhadap Dariya datang dari hati dan jiwa yang dalam.

Kepergian Dariya adalah akibat konflik dengan tokoh aku. Hal tersebut tampak dalam kutipan berikut Sejak aku mencintaimu, laut dan semuanya / Menjadikan air matamu meresap / Cintamu yang bar-bar...lebih besar dariku / Tapi mengapa...engkau begitu keras kepala. Tampak dalam kutipan puisi diatas bagaimana cinta dan konflik yang terjadi antara si aku dan Dariya. Bahkan si aku meyakini walaupun cinta Dariya adalah cinta yang liar (bar-bar), tetapi cinta Dariya sangat besar kepadanya. Kemudian dalam baris selanjutnya tampak si aku bertanya mengenai sikap dan kekakuan Dariya. Sikap kekakuan tersebutlah yang menjadikan Dariya pergi. kemudian si aku menyadari segala kesalahannya. Hal tersebut tampak dalam kutipan berikut Maafkan aku...jika engkau terus bermimpi / Dan memberimu pakaian sutra yang berbordir / Aku selalu beranganangan...andai engkau dekat dipelupuk mataku/. Dalam kutipan puisi tersebut tampak bagaimana si aku meminta maaf atas segala sikapnya. Apa yang tampak diberikannya lewat materi (baju sutra yang berbordir) ternyata tidak membahagiakan Dariya. Si aku juga meminta maaf karena hanya memberikan inpian yang indah pada kekasihnya. Dalam baris selanujtnya tampak si aku meminta kepada Dariya untuk memberikan pemahaman mengena dirinya dan kepribadiannya. Hal itu tampak dalam kutipan berikut Beri tahu saya siapa engkau? Sungguh yang kurasakan / Aku merasa seperti mengejar kelinci / Engkaulah misteri yang nyata dalam hidupku.

Dalam puisi Ukhibbuki Jiddan terdapat beberapa gaya bahasa. Gaya bahasa yang pertama adalah Polisindeton (kebalikan asindeton), yaitu gaya bahasa yang menyebutkan beberapa hal berturut-turut dengan menggunakan kata penghubung. Gaya bahasa tersebut tampak dalam kutipan puisi berikut Angin, dan Petir, dan awan, dan Guntur, dan salju dan api. Gaya bahasa tersebut merupakan gaya bahasa Pelisindeton, dimana penulis menyebutkan hal-hal yang berturut-turut dengan kata penghubung dan. Gaya bahasa ini berfungsi untuk memberikan penguatan keadaan tertentu.

Gaya bahasa lain adalah tasybih/Simile yaitu bahasa kiasan berupa pernyataan satu hal dengan hal lain dengan menggunakan kata-kata pembanding. Gaya bahasa Simile tampak dalam kutipan puisi berikut /Aku sangat mencintaimu / Dan aku tahu, aku berada di rimba matamu, sendiri berperang / Aku seperti kebanyakan orang gila yang mencoba berburu bintang. Dari kutipan diatas tampak bagaimana penulis sangat indah mengungkapkan rasa cinta yang begitu besar kepada kekasihnya. Si aku sangat sadar bahwa dia sedang sendiri berperang untuk mendapatkan cinta kekasihnya. Tampak si aku mengibaratkan dirinya dengan gaya bahasa simile seperti kebanyakan orang gila . Karena cintanya yang amat besar, si aku mengibaratkan dirinya seperti semua orang gila yang berusaha untuk berburu bintang. Kegilaan yang timbul dari si aku adalah karena cinta yang teramat besar. 
Majas lain adalah personifikasi, Personifikasi/Penginsanan adalah gaya bahasa yang mempersamakan benda-benda dengan manusia, punya sifat, kemampuan, pemikiran, perasaan, seperti yang dimiliki dan dialami oleh manusia. Gaya bahasa personifikasi tampak dalam kutipan berikut /Dan aku tahu waktu bercinta telah usai / Kata-kata yang indah telah mati/. Maksud dari kata indah yang mati adalah si aku sudah tidak mampu lagi menggambarkan lagi dengan kata-kata, karena kata-kata telah habis untuk menggambarkan cintanya.

Gaya bahasa lain adalah Hiperbola yaitu gaya bahasa berupa pernyataan yang sengaja dibesar-besarkan dan dibuat berlebihan. Dalam puisi Uckibbuki Jiddan, peneliti mendapatkan banyak sekali bentukbentuk dari gaya bahasa Hiperbola. Contoh dari gaya bahasa hiperbola tampak dalam kutipan puisi berikut /Aku sangat mencintaimu, dan aku tahu aku hidup terasing/. Kata hidup terasing merupakan bentuk majas hiperbola, dimana si aku membesar-besarkan kehidupannya yang terasa sepi sendiri, kesepiannya menjadikan ia merasa hidup terasing. Hal tersebut karena cintanya yang begitu besar terhadap kekasihnya. Kata lain yang termasuk dari gaya bahasa Hiperbola adalah seperti dalam kutipan puisi berikut Dan aku tahu, untuk sampai kepadamu / kepadamu harus bunuh diri. Kata bunh diri digunakan untuk mengambarkan bagaimana perjuangan si aku untuk mendapatkan kekasihnya, ia sangat sadar bahwa untuk mendapatkan kekasihnya haruslah dibayar dengan harga yang sangat mahal yaitu kematian.

Gaya bahasa hiperbola juga tampak dalam kutipan puisi berikut Dan aku telah membakar semua kapal-kapal yang ada dibelakangku, dimana si aku sudah sangat bertekat kuat dengan apa yang dicintainya. Kata sudah membakar semua kapal-kapal yang ada dibelakangnya adalah bentuk dari gaya bahasa hiperbola yang membesarbesarkan sebuah pekerjaan yang dilakukan oleh si aku, namun arti sesungguhnya si aku sudah bulat dengan cintanya dan tak ada pilihan lain. Bentuk lain dari gaya bahasa hiperbola tampak dari kutipan puisi berikut Dan jalan untuk bertemu dengan ayahmu / Dihadang dengan ribuan bala tentara. Tampak dalam kutipan diatas penulis inging menggambarkan bagaimana sulitnya untuk mendapatkan hati kekasihnya. Bahkan untuk mendapatkan restu dari orang tua kekasihnya pun sangat mustahil. Kesulitan yang dialami oleh aku diibaratkan seperti dihadang ribuan tentara.

Dari pengungkapam form gaya bahasa tersebut, maka makna dari puisi Uchibbuki Jiddan adalah cinta sejati dan perjuangan untuk mendapatkan cinta. Kata "Ukhibukki Jiddan" bermakna saya sangat mencintaimu. Kata sangat mencintaimu sendiri berarti upaya untuk mendapatkan cinta lewat perjuangan, karena kata tersebut berasal dari kata kerja yang menunjukkan suatu aktifitas. Kata perjuangan tampak dalam bait-bait puisi berikut Aku sangat mencintaimu / Aku tahu, jalan kemustahilan adalah panjang / Aku tahu bahwa engkau adalah wanita pujaan / Tapi, aku tidak punya pengganti. Dalam bait lain dinyatakan bahwa cinta si aku yang sangat besar terhadap kekasihnya digambarkan seperti perjuangan seorang diri dan dalam keterasingan, Engkau terasing...diantara kamu dan diantara aku / Angin, petir, awan, Guntur, salju dan api / Dan aku tahu, untuk sampai padamu...kepadamu harus bunuh diri.

Dalam bait lain dikatakan, bahwa si aku sadar bahwa rasa cintanya kepada kekasihnya adalah ketidakpastian, hal tersebut tampak dalam bait puisi berikut $A k u$ sangat mencintaimu, dan aku tahu, aku berlayar dilaut matamu tanpa kepastian / Aku meninggalkan pikiranku, dan aku berlari...berlari bersama kegilaanku. Dari kutipan puisi diatas, tampak sekali bagaimana aku sadar bahwa cintanya kepada kekasihnya sangat sulit, si aku menggambarkannya dengan kata-kata "aku berlayar dilaut matamu tanpa kepastian". Namun cintanya yang begitu besar meneguhkan hatinya. Hal tersebut digambarkan dalam bait selanjutnya bahwa dia meninggalkan segala logika fikiranyya dan berlari seperti orang gila.

Dalam bait lain dikatakan bahwa si aku sadar, bahwa dia merasa sendiri berjuang demi cintanya yang diibaratkan hidup sendiri berjuang dihutan matamu. Dia juga sadar bahwa dia seperti orang gila yang berburu bintang dilangit untuk mendapatkan kekasihnya. Hal yang sangat sulit mengenai cintanya tampak juga dari sikap orang tua kekasihnya. Hal tersebut tampak dalam kutipan puisi berikut Dan jalan sampai ke 
rumah ayahmu / Dikepung oleh ribuan tentara / Dan tetaplah cintaku, meskipun keyakinanku / Bahwa menyebut namamu adalah kekafiran. Meskipun sangat sulit untuk mencintai kekasihnya, si aku akan terus berusaha untuk mencintai dan mendapatkan kekasihnya. Usaha tersebut akan terus dilakukan walaupun sampai mati. Bahkan ia akan sangat senang jika si aku kemudian mati, sedangkan bibir kekasihnya mengucapkan kemenangan atas usahanya untuk mendapatkan cintanya.

Pada akhir puisinya ada diksi yang diungkakan Dan aku mengetahui ahir dari cerita itu / dan aku tetap mencintaimu / Aku sangat mencintaimu. Ungkapan yang sangat indah dari Nizar Qabbani, walaupun ia tahu akan gagal dengan cintanya, akan mati karena cintanya, walaupun demikian ia tetap mencintai kekasihnya.

\section{SIMPULAN}

Hasil analisis mengungkapkan terdapat berbagai ragam gaya bahasa yang digunakan oleh Nizar Qabbani. Gaya bahasa yang dimaksud adalah personifikasi, metafora, dan simile. Ini sebagai indikasi Nizar Qabbani bermain puisi dengan dengan kata-kata dan gaya bahasa. Gaya bahasa tersebutlah yang membuat puisinya sangat hidup dan Indah.

Adapun makna yang dapat diungkapkan ketiga puisinya berupa makna amarah, cinta dan janji dalam puisi Ighdab. Adapun puisi Aina Adzhabu mempunyai makna cinta sejati dan rasa kehilangan terhadap kekasihnya, sedangkan puisi Uchibbuki Jiddan bermakna tentang cinta sejati dan perjuangan.

\section{DAFTAR PUSTAKA}

Abrams, M. H. (1981). A Glossary of Literary Terms. New York: Holt, Rinehart and Winston

Aminuddin. (1987). Pengantar Apresiasi Karya Sastra. Bandung: CV. Sinar Baru.

Hartoko, Dick, Rahmanto, B. (1986). Pemandu di Dunia Sastra. Yogyakarta: Kanisius.

Hewkes, Terrence.(1977). Structuralism and Semiotic. Methuen and Co.Ltd London.

Huluhi, Shaleh. (2011). Dhawahir al-Uslubiyah Li Syi'ri Nizar Qobbani. Janifi, 18 (1) 65-67.

Junus, Umar. (1985). Resepsi Sastra Sebuah Pengantar. Jakarta : PT. Gramedia.

Pradopo, Rachmat Djoko. 2002. Kritik Sastra Indonesia Modern. Yogyakarta: Gama Media

Qabbani, Nizar. (1982). 100 Risalah Hubb. File Pdf . tanpa penerbit.

Qowamisy, Hisyam. (2009). Rukyat wa Tasykil fi Syi'ri Nizar Qobbany. Adabiyah, 10 (2) 50-53.

Ratna, Nyoman Kutha. (2007) Penelitian Sastra; teori, Metode dan Tehnik. Yogyakarta: Pustaka Pelajar.

Shaleh, Ali Mushtafa. (2012). At-Tanash al-Qur'ani fi Syi'ri nizar Qobbani. Dirasah Adabiyat, 19 (7) 26-29.

Siswantoro, (2010). Metode Penelitian Sastra : Analisis Struktur Puisi. Yogyakarta: Pustaka Pelajar.

Suroso, dkk. (2008). Kritik Sastra: Teori, Metode dan Aplikasi. Yogyakarta: Elmatera Publising.

Teeuw. A. (1984). Sastra dan Ilmu Sastra. Jakarta: PT Pustaka Jaya.

Van Luxemburg, Jan, dkk. (1986). Pengantar Ilmu Sastra. Tarjamah, oleh Dick Hartono. Jakarta: Gramedia. 
Yusuf, Kamal. (2009). Teori Sastra: Modul Mata Kuliah. Bahasa dan Sastra Arab. Surabaya: IAIN Sunan Ampel .

Zuhdy, Halimi. (2015). At-Tanash wa Muqoribatunnas, li syi'ri Nizar Qobbani. Humaniora UIN Malang. 